\title{
The Effect of Single Parent Parenting, Peer Conformity, and Self-Concept on Adolescent Religiosity
}

\author{
Rina Setyaningsih ${ }^{1}$, Nyayu Khodijah ${ }^{2}$, Munir $^{3}$
}

DOI: $10.35445 /$ alishlah.v13i3.822

\begin{abstract}
Article Info
Abstract

Keywords:

Parenting, Single parent (father), Peer conformity, Self-concept, Religiosity

The study aimed to prove the effect of single-parent (father) parenting and peer conformity on religiosity in adolescents in the Marga Sekampung sub-district, East Lampung district. The study was a quantitative study with a population and sample of 51 adolescents aged 10-16 years. Data was collected through questionnaires and documentation. Instrument validity was through Product Moment correlation and instrument reliability through the split-half technique. The data analysis technique is through the prerequisite test with normality and homogeneity tests, variable description, and the hypothesis test with simple linear regression and multiple regression tests. The study found that the effect of single-parent (father) parenting, peer conformity, and self-concept together on adolescent religiosity was $82.8 \%$ and $\mathbf{1 7 . 2} \%$ affected by other factors.
\end{abstract}

Kata kunci:

Pola asuh, Single parent (ayah) Konformitas teman sebaya, Konsep diri, Religiusitas

\begin{abstract}
Abstrak
Penelitian ini bertujuan untuk membuktikan pengaruh pola asuh single parent (ayah) dan konformitas teman sebaya terhadap religiusitas pada remaja di kecamatan Marga Sekampung kabupaten Lampung Timur. Penelitian ini merupakan penelitian kuantitatif dengan populasi dan sampel sebanyak 51 remaja berumut 10-16 tahun. Pengumpulan data dilakukan melalui angket dan dokumentasi. Validitas instrumen melalui korelasi Product Moment dan reliabilitas instrument melalui teknik belah dua. Teknik analisis data melalui uji prasyarat dengan uji normalitas dan uji homogenitas; deskripsi variabel; dan uji hipotesis dengan uji regresi linier sederhana dan uji regresi ganda. Penelitian ini menemukan bahwa adanya pengaruh pola asuh single parent (ayah), konformitas teman sebaya, dan konsep diri secara bersama-sama terhadap religiusitas remaja sebesar $82,8 \%$ dan $17,2 \%$ dipengaruhi oleh faktor lain.
\end{abstract}

\footnotetext{
${ }^{1}$ IAI An Nur Lampung, Indonesia

Email: rina.setyaningsih15@gmail.com

${ }^{2}$ UIN Raden Fatah Palembang, Indonesia

Email: nyayukhodijah_uin@radenfatah.ac.id

${ }^{3}$ UIN Raden Fatah Palembang, Indonesia

Email: munir_uin@radenfatah.ac.id
} 


\section{INTRODUCTION}

Adolescence was a period of human life that was very important for every human being towards the adult stage. The transition from childhood to adolescence was marked by biological, emotional, cognitive, and social changes. Biological processes were physical changes that included brain development, weight and height gain, hormonal changes, and motor skills. Cognitive processes included changes in thought, intelligence, and language. Meanwhile, emotional and social processes had changes in individual relationships with other humans, emotions, personality, and social (Elfida, 2005; Santrock, 2006; Warsiyah, 2018). This transition period must get supervision from parents so as not to fall into deviant behavior.

Deviations that occur in adolescence can be caused by attitudes and behaviors that were far from religious values (Smith, 2003; Susanti \& Handoyo, 2015). This was because religion had become an important part of human life (Koenig et al., 2005). After all, religion has become part of the cultural value system of society (Stark \& Glock, 1993) so that it can affect human behavior. Someone who had been able to practice his religious teachings well, then his behavior will also be good. This was because religion can control human behavior by the values of religious teachings. Religious guidance can be obtained from the surrounding environment, namely the main family environment, school environment, and community environment. The family environment was the first to instill religious teachings in their children. Parents first introduced religion in the family environment to their children, so parents played an important role in their children's religious beliefs (Butler-Barnes et al., 2017). Parents also acted as role models in carrying out religious teachings properly and correctly. Parents' religious behavior in everyday life was an example for children in carrying out religious teachings (Uhbiyati, 2013). Religious socialization carried out by parents in the family environment affects the religious experience of adolescents (Uhbiyati, 2013). The role of parents, namely fathers and mothers, was very necessary for raising children, especially providing religious teachings to their children.

Parenting was the duty of parents in a family that is in the community. The family was the main place where children developed and raised their parents to become mature and independent individuals. Parents' attitude in raising children largely determined the relationship between children and their parents, the parenting process parents did to their children, and what parents instilled in their children from an early age. This was focused on the parenting pattern applied by parents, which was a method chosen and carried out by parents in raising children (Shundy \& Purwandari, 2015). In parenting, the need for family harmony, especially father and mother, otherwise it will be a factor causing juvenile delinquency (Hawari, 1997; Isminayah, 2016).

The family also occupied the most important position in the development of children towards adulthood because the family environment was the first and foremost place for children to form a relationship with their parents and siblings before establishing relationships with other people in their environment. In addition, the family had a great effect on the development of children's behavior. In the family, children began to learn to imitate behavior with people who interacted a lot with children. Changes in the family that will occur include changes in the roles and duties that single parents must bear in raising children. The burden of tasks that single parents must bear was related to fulfilling economic, affection, and physical needs for children, which meant that the role and tasks borne by single parents were very heavy (Shundy \& Purwandari, 2015). Father and mother figures were needed in the right parenting pattern towards adulthood and independence (Padjrin, 2016).

The second environment that provided information for children was the school. Schools were formal educational institutions where students learned various knowledge, skills, norms, and values. The school was also a social environment that could allow students to interact socially with school residents, teachers, staff, and especially their peers. Peers were one of the important socialization agents for adolescents whose position cannot be replaced by parents or teachers. Equality in age between peers and the need to socialize leads to the formation of peer groups. Peer groups provided 
opportunities for adolescents to learn to live together with people other than family. In peer groups, they can learn about the values and norms that are applied in peer groups (Wood et al., 2007).

In interactions with peers, there was a process of imitation, namely imitating their peers' behavior in everyday life, including religious behavior. Teenagers who hang out with obedient peers in carrying out their religion will create opportunities for these teenagers to be more diligent in carrying out religious teachings than teenagers who hang out with friends who were not diligent in carrying out religious teachings. And vice versa, if you make friends with bad people, bad behavior will also be imitated. The effect of peers on adolescents was positive and sometimes also negative. This was the need for the role of parents to direct and give consideration to children to be good at choosing friends. Based on research conducted, peer conformity affects student religiosity (Cornwall, 1987; Paninten \& Indrawati, 2020; Siroj et al., 2019)

In addition to the external factors above, adolescent self-concept also affects religiosity. According to Shavelson and Roger, self-concept was formed from experiences and interpretations of the environment, the views of others, attributes, and their behavior (Shavelson \& Bolus, 1982). The development of this self-concept affected the behavior displayed, so how the treatment and words of others about the individual will be placed as a guide for himself. Adolescents who had a positive selfconcept were generally able to cope with themselves, pay attention to things around them, and have the ability to interact socially (Sahrudin, 2017).

Based on the results of the pre-survey, it was known that the religiosity of adolescents was classified as lacking because adolescents lack religious attitudes in daily life. At the same time, single parent (father) parenting was relatively good. Peer conformity was quite good. In terms of friendship, they often gathered at one's house friends to do homework, plan something, look for tasks together, and be noisy together positive and negative things. However, the self-concept in adolescents was still relatively lacking because teenagers followed the wishes of their peers more than their desires. They were more confident when they were in one group mates in action. The study sought to prove whether single-parent (father) parenting and peer conformity on religiosity partially or simultaneously in adolescents in the Marga Sekampung sub-district, East Lampung district.

\section{METHOD}

The study used a type of quantitative research. The research was conducted for six months, from October 2020 to April 2021, in the Marga Sekampung sub-district, East Lampung District. The population and samples used were all teenagers aged 10-16 years in the Marga Sekampung -subdistrict, which amounted to 51 teenagers. Data was collected through questionnaires and documentation. The instrument's validity was tested by correlation of the item scores with the total score using the correlation formula of "Product Moment (Pearson)". The instrument's reliability in the study will be analyzed using the split-half technique by correlating the total odd versus even scores. Data analysis technique through prerequisite test with normality and homogeneity tests; variable description; and hypothesis test with simple linear regression and multiple regression tests.

\section{FINDINGS AND DISCUSSION}

\section{Variable Data Description}

a. Data on single parent (father) parenting

Table 1. Single parent (father) parenting

\begin{tabular}{lc}
\hline \multicolumn{1}{c}{ Description } & Score \\
\hline Mean & 1.07962 \\
Median & 1.09002 \\
Modus & 116.00 \\
Std. Deviation & 2.079611 \\
\hline
\end{tabular}

From table 1, it can be seen that the variable score of single parent (father) parenting varied from the lowest score of 70 to a maximum score of 150 . Based on basic statistical calculations, 
the numbers obtained were mean $=1.07962$, median $=1.09002$, modus $=116.00$ and standard deviation $=2.079611$. The calculation showed that the mean and median were not much different. This indicated that the single parent parenting variable (father) score tended to be normally distributed.

b. Peer conformity

Tabel 2. Peer Conformity

\begin{tabular}{lc}
\hline \multicolumn{1}{c}{ Description } & Score \\
\hline Mean & 1.08222 \\
Median & 1.09002 \\
Modus & 109.00 \\
Std. Deviation & 2.161511 \\
\hline
\end{tabular}

From table 2, it can be seen that the score of the peer conformity variable varied from the lowest score of 76 , to a maximum score of 163 . Based on basic statistical calculations, the numbers obtained were mean $=1.08222$, median $=1.09002$, modus $=109.00$ and standard deviation $=$ 2.161511. The calculation showed that the mean and median were not much different. This indicated that the score of the peer conformity variable tended to be normally distributed.

c. Self-concept

Table 3. Self-concept

\begin{tabular}{lc}
\hline \multicolumn{1}{c}{ Description } & Score \\
\hline Mean & 1.09652 \\
Median & 1.10002 \\
Modus & 112.00 \\
Std. Deviation & 2.025421 \\
\hline
\end{tabular}

From table 3, it can be seen that the score for the self-concept variable varied from the lowest score of 75 to a maximum score of 161 . Based on the basic statistical calculations, the numbers obtained were mean $=1.09652$, median $=1.10002$, mode $=112.00$ and standard deviation $=$ 2.025421. The calculation showed that the mean and median were not much different. This indicated that the self-concept variable scores tended to be normally distributed.

d. Adolescent religiosity

Table 4. Adolescent religiosity

\begin{tabular}{lc}
\hline \multicolumn{1}{c}{ Description } & Score \\
\hline Mean & 1.17122 \\
Median & 1.12002 \\
Modus & 101.00 \\
Std. Deviation & 1.783331 \\
\hline
\end{tabular}

From table 4, it can be seen that the variable scores of adolescent religiosity varied from the lowest score of 72 to the maximum score of 172 . Based on basic statistical calculations, the numbers obtained were mean $=1.17122$, median $=1.12002$, mode $=101.00$ and standard deviation $=1.783331$. This calculation shows that the mean and median were not much different. This indicated that the scores of adolescent religiosity variables tended to be normally distributed.

\section{Normality Test}

Table 5. Summary of normality test results

\begin{tabular}{lccc}
\hline \multicolumn{1}{c}{ Variable } & $\begin{array}{c}\text { Kolmogorov } \\
\text { Smirnov }\end{array}$ & Sig & Description \\
\hline Single parent (father) parenting $\left(\mathrm{X}_{1}\right)$ & .675 & 0,752 & Normal \\
Peer Conformity $\left(\mathrm{X}_{2}\right)$ & .765 & 0,602 & Normal \\
Self-concept $\left(\mathrm{X}_{3}\right)$ & 900 & 0,393 & Normal \\
Adolescent Religiosity $(\mathrm{Y})$. & 1.406 & 0,38 & \\
\hline
\end{tabular}


Based on table 5 , it can be concluded that the single parent (father) parenting (X1), peer conformity (X2), and self-concept $\left(\mathrm{X}_{3}\right)$ that had been tested using SPSS were normally distributed because they had met the data analysis requirements. Furthermore, the data that had been tested for normality will be re-tested at the linearity test stage. The data that had been normally distributed, of course, the data has met the requirements of research data analysis.

\section{Linearity Test}

Table 6. Summary of Linearity test results

\begin{tabular}{cccc}
\hline Variabel & F $_{\text {hitung }}$ & $\mathrm{P}_{\text {value }}$ & Description \\
\hline X1 denganY & 1.661 & 0,155 & Linier \\
X2 denganY & 1,262 & 0,329 & Linier \\
X3 denganY & 2.042 & 0,077 & Linier \\
\hline
\end{tabular}

Based on the results of the linearity test of the variable data of single parent (father) parenting $(\mathrm{X} 1)$ with Fhit $=1.661$ with p-value $=0.155>0.05$, peer conformity $(\mathrm{X} 2)$ with Fhit $=1.262$ with $\mathrm{p}$-value $=0.329>0,05$, and self-concept $\left(\mathrm{X}_{3}\right)$ with Fhit $=2,042$ with $\mathrm{p}$-value $=0,077>0,05$ on the data of adolescent religiosity variable $(\mathrm{Y})$. This meant that Ho was accepted, or the regression equation for religiosity ( $\mathrm{Y}$ ) on single parent (father) parenting (X1), peer conformity (X2), and self-concept $\left(\mathrm{X}_{3}\right)$ was linear or in the form of a linear line. Thus, the data that had met the linearity requirements can be analyzed further as valid research data.

\section{Hypothesis Test}

a. First hypothesis

The first hypothesis that will be tested for truth in the study was "single parent (father) parenting had a positive and significant effect on adolescent religiosity in Marga Sekampung sub-district, East Lampung."

Following were the results of the data analysis of the first hypothesis testing in the study using a simple linear regression statistical test using the SPSS type 16.0 program application, the price coefficient for the direction of simple linear regression of single parent (father) parenting (b) was 0.737 with a constant (a) of 37.592 so that the equation Simple linear regression was $\hat{Y}_{1}=a+b X=37.592+0.737 x$. The calculation results using the SPSS program are as follows:

Table 7. The results of simple linear regression calculation of the effect of singleparent (father) parenting on adolescent religiosity

\begin{tabular}{|l|l|r|r|r|r|r|}
\hline \multirow{2}{*}{ Model } & \multicolumn{2}{|c|}{$\begin{array}{c}\text { Unstandardized } \\
\text { Coefficients }\end{array}$} & \multicolumn{2}{c|}{$\begin{array}{c}\text { Standardized } \\
\text { Coefficients }\end{array}$} & \multirow{2}{*}{ Sig. } \\
\cline { 3 - 7 } \multicolumn{2}{c|}{} & B & $\begin{array}{c}\text { Std. } \\
\text { Error }\end{array}$ & Beta & \\
\hline \multirow{2}{*}{1} & (Constant) & 37.592 & 6.410 & & 5.865 & .000 \\
\cline { 2 - 6 } & $\begin{array}{l}\text { Single parent } \\
\text { (father) parenting }\end{array}$ & .737 & .058 & .875 & 12.636 & .000 \\
\hline
\end{tabular}

Based on table 7, coefficients a showed that the simple linear regression equation model to estimate Adolescent Religiosity which was affected by a single parent (father) parenting was $\hat{Y}_{1}=a+b X=37.592+0.737 x$, where $\mathrm{Y}$ was adolescent religiosity. At the same time, $\mathrm{X}$ was single parent (father) parenting. Furthermore, the significance of the simple linear regression equation was tested by applying analysis of variance using the SPSS 16.0 program with the criteria used if the value of $\mathrm{r}$ was greater than $a$ certain value, then Ho was accepted. On the other hand, if the value of $r$ was less than $(<) a$ certain value, then Ho was rejected. The regression significance test results are as shown in table 8. 
Table 8. The results of the test of the significance of simple linear regression

\begin{tabular}{|l|l|r|r|r|r|c|}
\hline \multicolumn{2}{|l|}{ Model } & $\begin{array}{c}\text { Sum of } \\
\text { Squares }\end{array}$ & $\mathrm{df}$ & $\begin{array}{c}\text { Mean } \\
\text { Square }\end{array}$ & $\mathrm{F}$ & Sig. \\
\hline \multirow{2}{*}{1} & Regression & 11744.683 & 1 & 11744.683 & 159.678 & $.000^{\mathrm{a}}$ \\
\cline { 2 - 7 } & Residual & 3604.063 & 49 & 73.552 & & \\
\cline { 2 - 7 } & Total & 15348.745 & 50 & & & \\
\hline
\end{tabular}

Based on table 8, it appeared that the value of $a$ or significance was smaller than the level $a$ used, namely 0.05 or $0.000<0.05$, so Ho was rejected. This meant that there was a positive and significant effect between single parent (father) parenting and adolescent religiosity.

This indicated that the simple linear regression equation model of $\hat{Y}_{1}=a+b X=37.592+0.737 x$ was significant and can explain the direction of the strength of the effect of single-parent (father) parenting on adolescent religiosity.

From the regression equation $\hat{Y}_{1}=a+b X=37.592+0.737 x$, it can be explained that there was a positive and significant effect on single parent (father) parenting with adolescent religiosity, where if the score for single parent (father) parenting increases, adolescent religiosity also increases. Thus, if the single parent (father) parenting factor increased by 0,737 , it would be followed by an increase in adolescent religiosity of 37,592. The regression coefficient of 0.737 indicated the magnitude of the addition of adolescent religiosity for each increase in single-parent (father) parenting.

Based on the description of the analysis results above, it can be concluded that there was a significant effect between single parent (father) parenting and adolescent religiosity in the Marga Sekampung sub-district, East Lampung. The magnitude of the effect of single-parent (father) parenting on adolescent religiosity can be seen in table 9.

Table 9. The magnitude of the effect of single-parent (father) parenting on adolescent religiosity

\begin{tabular}{lrrrr}
\hline Model & R & R Square & $\begin{array}{c}\text { Adjusted R } \\
\text { Square }\end{array}$ & $\begin{array}{c}\text { Std. Error of the } \\
\text { Estimate }\end{array}$ \\
\hline 1 & $.875^{\mathrm{a}}$ & .765 & .760 & 8.57626 \\
\hline
\end{tabular}

In table 9, it was known that the effect of single-parent (father) parenting on adolescent religiosity was 0.875 , or it can be said that changes in adolescent religiosity were affected by single parent (father) parenting variables of $76.5 \%$, which were categorized as a high effect. In comparison, the remaining $24.5 \%$ was affected by other variables outside the model.

b. Second hypothesis

The second hypothesis that will be tested for truth in the study was "peer conformity had a positive and significant effect on adolescent religiosity in Marga Sekampung sub-district, East Lampung".

Following were the results of the data analysis of testing the second hypothesis in the study using a simple linear regression statistical test using the SPSS type 16.0 program application. The coefficient of simple linear regression direction was Peer Conformity (b) of 0.737 with a constant (a) of 37.565. So the simple linear regression equation was $\hat{Y}_{2}=a+b X=37,565+0.737 x$. The following were the results of the calculation using the SPSS program:

Table 10. The results of simple linear regression calculations the effect of peer conformity on adolescent religiosity

\begin{tabular}{|c|c|c|c|c|c|c|}
\hline \multirow{2}{*}{\multicolumn{2}{|c|}{ Model }} & \multicolumn{2}{|c|}{$\begin{array}{l}\text { Unstandardized } \\
\text { Coefficients }\end{array}$} & \multirow{2}{*}{$\begin{array}{c}\begin{array}{c}\text { Standardize } \\
\text { d } \\
\text { Coefficients }\end{array} \\
\text { Beta }\end{array}$} & \multirow[t]{2}{*}{$\mathrm{t}$} & \multirow[t]{2}{*}{ Sig. } \\
\hline & & $\mathrm{B}$ & Std. Error & & & \\
\hline \multirow[t]{2}{*}{1} & (Constant) & 37.565 & 5.886 & & 6.382 & .000 \\
\hline & peer conformity & .737 & .053 & .892 & 13.776 & .000 \\
\hline
\end{tabular}


Table 10 coefficients a showed that the simple linear regression equation model for estimating adolescent religiosity was effectd affected by peer conformity $\hat{Y}_{2}=a+b X=37.565+0.737 x$, where $\mathrm{Y}$ was adolescent religiosity attitude, while $\mathrm{X}$ was peer conformity.

Furthermore, the significance of the simple linear regression equation was tested by applying analysis of variance using the SPSS 16.0 program with the criteria used if the value of $r$ was greater than $a$ certain value, then Ho was accepted. On the other hand, if the value of $r$ was less than $(<) a$ certain value, then Ho was rejected. The results of the regression significance test are in table 11.

Table 11. The results of the test of the significance of simple linear regression

\begin{tabular}{llrrrrr}
\hline \multicolumn{1}{l}{ Model } & \multicolumn{1}{c}{$\begin{array}{c}\text { Sum of } \\
\text { Squares }\end{array}$} & Df & \multicolumn{1}{c}{$\begin{array}{c}\text { Mean } \\
\text { Square }\end{array}$} & F & Sig. \\
\hline 1 & Regression & 12198.860 & 1 & 12198.860 & 189.767 & .000 $^{\text {a }}$ \\
& Residual & 3149.885 & 49 & 64.283 & & \\
& Total & 15348.745 & 50 & & & \\
\hline
\end{tabular}

Based on table 11, it appeared that the value or significance was smaller than the level used (i.e. 0.05) or $0.000<0.05$, so Ho was rejected. This meant a positive and significant effect between peer conformity and adolescent religiosity. This indicated that the simple linear regression equation model of $\hat{Y}_{2}=a+b X=37.565+0.737 x$ was significant and can explain the direction of the strength of the effect of peer conformity on adolescent religiosity.

From the regression equation, it can be explained that there was a positive and significant effect of peer conformity on adolescent religiosity. If peer conformity scores increased, adolescent religiosity attitudes also increased. Thus, if the peer conformity factor increased by 0.737 , it would be followed by an increase in adolescent religiosity by 37.565 . The regression coefficient of 0.737 indicated the magnitude of the increase in the level of adolescent religiosity for each increase in peer conformity.

Based on the description of the analysis results above, it can be concluded that there was a significant effect between peer conformity and adolescent religiosity. This meant that the better the conformity of peers, the higher adolescents' religiosity. The magnitude of the effect of peer conformity on adolescent religiosity can be seen in table 12 .

Table 12. The effect of peer conformity on adolescent religiosity
\begin{tabular}{crrrr} 
Model & $\mathrm{R}$ & $\mathrm{R}$ Square & $\begin{array}{c}\text { Adjusted R } \\
\text { Square }\end{array}$ & $\begin{array}{c}\text { Std. Error of } \\
\text { the Estimate }\end{array}$ \\
\hline 1 & $.892^{\mathrm{a}}$ & .795 & .791 & 8.01769 \\
\hline
\end{tabular}

In table 12, it was known that the effect of peer conformity on adolescent religiosity was 0.892 , or it can be said that changes in adolescent religiosity were affected by peer conformity variables of $79.5 \%$, which were categorized as a high effect.

c. Third hypothesis

The third hypothesis that will be tested for truth in the study was "self-concept had a positive and significant effect on adolescent religiosity in Marga Sekampung sub-district, East Lampung. Following were the results of the data analysis of testing the third hypothesis in the study with a simple linear regression statistical test using the SPSS type 16.0 program application, it can be obtained that the coefficient of self-concept simple linear regression $(b)$ was 0.782 with a constant (a) of 31.361. So the simple linear regression equation was $\hat{Y}_{3}=a+b X=31,361+0.782 x$. The following was the result of the calculation using the SPSS program: 
Table 13. The results of simple linear regression calculation of the effect of self-concept on adolescent religiosity

\begin{tabular}{|c|c|c|c|c|c|c|}
\hline \multicolumn{2}{|c|}{ Model } & \multicolumn{2}{|c|}{ Unstandardized Coefficients } & \multirow{2}{*}{$\begin{array}{c}\begin{array}{c}\text { Standardized } \\
\text { Coefficients }\end{array} \\
\text { Beta }\end{array}$} & \multirow[t]{2}{*}{$\mathrm{t}$} & \multirow[t]{2}{*}{ Sig. } \\
\hline & & $\mathrm{B}$ & Std. Error & & & \\
\hline \multirow[t]{2}{*}{1} & (Constant) & 31.361 & 5.873 & & $5 \cdot 340$ & .000 \\
\hline & Self-Concept & .782 & .053 & .905 & 14.851 & .000 \\
\hline
\end{tabular}

Table 13 coefficients a showed that the simple linear regression equation model for estimating adolescent religiosity, which was effectd by self-concept, was $\hat{Y}_{3}=a+b X=31,361+0.782 x$, where $\mathrm{Y}$ was adolescent religiosity, while $\mathrm{X}$ was self-concept.

Furthermore, the significance of the simple linear regression equation was tested by applying analysis of variance using the SPSS 16.0 program with the criteria used if the value of $r$ was greater than $a$ certain value, then Ho was accepted. On the other hand, if the value of $r$ was less than $(<) a$ certain value, then Ho was rejected. The results of the regression significance test in table 14:

Table 14. The results of testing the significance of simple linear regression on the effect of self-concept on adolescent religiosity

\begin{tabular}{|l|l|r|r|r|r|c|}
\hline \multicolumn{2}{|l|}{ Model } & $\begin{array}{c}\text { Sum of } \\
\text { Squares }\end{array}$ & \multicolumn{1}{c|}{ Df } & $\begin{array}{c}\text { Mean } \\
\text { Square }\end{array}$ & F & Sig. \\
\hline \multirow{2}{*}{1} & Regression & 12558.564 & 1 & 12558.564 & 220.548 & $.0^{\text {a }}$ \\
\cline { 2 - 8 } & Residual & 2790.181 & 49 & 56.942 & & \\
\cline { 2 - 8 } & Total & 15348.745 & 50 & & & \\
\hline
\end{tabular}

Based on table 14, it appeared that the value or significance was smaller than the level used (i.e. 0.05 ) or $0.000<0.05$, so Ho was rejected. This meant a positive and significant effect between self-concept and adolescent religiosity. This indicated that the simple linear regression equation model of $\hat{Y}_{3}=a+b X=31,361+0.782 x$ was significant and can explain the direction of the strength of the effect of self-concept on adolescent religiosity.

From the regression equation, it can be explained that there was a positive and significant effect of self-concept on adolescent religiosity. If the self-concept score increased, adolescent religiosity also increased. Thus it can also be explained that if the self-concept factor increases by 0.782 , it will be followed by an increase in adolescent religiosity by 31,361 . The regression coefficient of 0.782 indicated the magnitude of the increase in the level of adolescent religiosity for each increase in self-concept.

Based on the description of the analysis results above, it can be concluded that there was a significant effect between the effects of self-concept on adolescent religiosity in the Marga Sekampung sub-district, East Lampung. This meant that the higher the self-concept, the higher adolescents' religiosity in the Marga Sekampung sub-district, East Lampung District.

The magnitude of the effect of self-concept on adolescent religiosity in Marga Sekampung Lampung Timur sub-district can be seen in table 14:

Table 14. The effect of self-concept on adolescent religiosity

\begin{tabular}{lrrrr}
\hline Model & R & R Square & $\begin{array}{c}\text { Adjusted R } \\
\text { Square }\end{array}$ & $\begin{array}{r}\text { Std. Error of } \\
\text { the Estimate }\end{array}$ \\
\hline 1 & $.905^{\mathrm{a}}$ & .818 & .815 & 7.54602 \\
\hline
\end{tabular}

In table 14, it was known that the effect of self-concept on adolescent religiosity was 0.905 or it can be said that changes in adolescent religious attitudes were affected by self-concept variable of $81.8 \%$, which was categorized as strong/high effect.

d. Fourth hypothesis

The fourth hypothesis proposed was "single parent (father) parenting, peer conformity and selfconcept together on the attitude of religiosity of adolescents in Marga Sekampung, East 
concept. Together, $82.8 \%$ of adolescent religiosity was categorized as having a strong/high effect, while the remaining $\mathbf{1 7 . 2 \%}$ was affected by other variables outside the model.

Based on the table above, it can be explained that there was an effect of single-parent (father) parenting, peer conformity, and self-concept together on adolescent religiosity or it can be said that single parent (father) parenting, peer conformity, and self-concept together If the same was increasing, it would be followed by an increase in adolescent religiosity. Thus it can be understood that single-parent parenting (father), peer conformity, and self-concept together have a positive effect on adolescent religiosity.

\section{Single parent (father) parenting on adolescent religiosity}

There was a significant effect between single parent (father) parenting and adolescent religiosity in Marga Sekampung, East Lampung District. This meant that the better the single parent (father) parenting, the more the youth's religiosity will increase. The results of the study were in line with research by Aliyah (2017), Sisrazeni (2018), Sari (2019), Retnoningtyas (2010), and Suci (2018) that there was an effect between single parent (father) parenting on children's religious behavior. Parenting used were democratic parenting and permissive parenting. But what dominated its use was permissive parenting.

Mansur (2005) explained that parenting was the best way to educate children as an embodiment of a sense of parental responsibility. Parenting as a form of guidance contributed to the formation of children's religious behavior. Tafsir defined parenting as meant education, while education was conscious guidance by educators on the physical and spiritual development of students towards the formation of the main personality (Danny, 1991). Kohn (2011) also provided an understanding that parenting was the attitude of parents in dealing with their children. This attitude can be seen from various aspects, including how parents give rules to their children, how to give gifts and punishments, how parents show authority, and how parents pay attention to or respond to the child's wishes. Parenting was usually done by both parents. However, some families only had one parent who was commonly referred to as single parent.

Papalia (2010) defined single parenting as divorce or separation, birth out of wedlock, or death. Hurlock (1989) argued that single parents were parents, both mother and father, who were responsible for children after the death of their spouse, divorce, or the birth of children out of wedlock. Surya (2003) argued that single parents were parents in one family who lived alone, namely only the father or mother.

Perlmutter \& Hall (1985) ) explained that there were two kinds of single parents, first, namely: single-parent mother was the mother as a single parent must replace the father's role as the head of the family, decision-maker, breadwinner in addition to his role in taking care of the household, raising, guiding and fulfilling psychological needs of their children. Second, the single parent father was that the father as a single parent must replace the mother's role as a housewife who did household chores such as cleaning the house, cooking, and managing household income and expenses, while also paying attention to and meeting the physical and psychological needs of their children. In addition to the obligations as the head of the household who must earn a living for his family.

There were differences in parenting between single-parent mothers and single-parent fathers. The difference between single-parent mothers and single-parent fathers' parenting lies in communication, control, regulation, and punishment for children. Communication in single-parent fathers was not well established between fathers and children. In single-parent mothers, communication was well established but not warm. There was no control exercised on children in single-parent fathers, while in single parent mothers, the control exercised on children was low. In single-parent fathers, the rules and punishments applied did not exist, while in single-parent mothers, they were less consistent in applying regulations and punishments to children (Shundy \& Purwandari, 2015). 
Parenting given to children was one form of da'wah in the family in the form of guidance. Guidance was the assistance given to someone so that they could develop their potential and were responsible for overcoming the problems of their life (Gunarsa, 2007), both personally, socially, and religiously. Guidance, in general, was very important for the development and path of a child's life in achieving his future.

There were several things that parents needed to do in providing guidance to their children. First, helping children understand the position and role of each according to gender. Mutual respect and help each other carry out good deeds and please Allah. Second, helping children recognize and understand the values that govern family life, neighbors, and community and implement them. Third, encourage children to seek world knowledge and religious knowledge so that they are able to realize themselves as individuals and as members of a believing community.

Fourth, helping children enter social life gradually so that they can be free from dependence on their parents and take responsibility for their attitude and behavior. Fifth, encourage children to work independently and participate in carrying out religious activities in the family and community. Children gained direct experience to form good religious behavior (Mansur, 2005). This showed an integration between parenting and Islamic family guidance, both of which aimed to develop the potential that exists in humans.

Children needed guidance and guidance, in line with the stage of development they were experiencing. The most decisive figures in cultivating a sense of religiosity were his parents (Raharjo, 2002). This showed that there was an integration between parental guidance in the form of parenting and da'wah, both of which aimed to form positive religious behavior.

\section{Peer conformity to adolescent religiosity}

There was a significant effect between peer conformity and adolescent religiosity. This meant that the better the conformity of peers, the higher adolescents' religiosity. The results of the study were in line with Abidin's research (2019) that there were significant effects between peer conformity on positive and negative behavior, such as several studies on peer conformity to delinquency (Hariz, 2013; Hartaty \& Azis, 2014; Saputro \& Soeharto, 2012), moral intelligence (Adiyanti \& Sofia, 2014), lifestyle (Safitri, 2018), aggressive behavior (Prayugo \& Suroso, 2018), and others. Peer conformity can have an effect on the positive and negative behavior of adolescents. This was where the role of parents was needed to guide and direct their children so that they could choose associations that had a positive impact.

Adolescence was the most important period in achieving self-identity, where a teenager tended to be seen in peers or peer groups as a social group or reference group. Teenagers always bound themselves to a group because a group had demands that must be met by every teenager who wanted to join. Such behavior was an expression of feelings that the social environment wanted to accept or reflect "prestige" to be accepted by other parties, especially peers (Perdana \& Mujiasih, 2018).

Peer conformity was important in positive ways such as protecting friends, learning together, exchanging information, and working together. However, some peer conformities led to negative things, such as ostracizing other groups, acting criminally, and not respecting the opinions of others. This was to be avoided but not all conformity peers behave negatively. Back to parents who provided religious education in the family. Therefore, parents had an important role in fostering the morals of their children.

Peers were children or adolescents with more or less the same level of maturity or age. One of the most important functions of peer groups was to provide information and comparisons about the world outside the family. Through peer groups, individuals received feedback from their peers about their abilities. Teenagers judged what they did, whether he was better than their friends, the same, or worse than other teenagers did. This will be difficult to do because siblings were usually older or younger (not the same age) (Santrock, 2012). Peer interaction allowed the identification, cooperation, and collaboration processes (Gladding, 1995). These processes will color the process of forming a typical behavior in adolescents. Friendship among peers had an important meaning for 
adolescents. According to Gottman \& Parker, friendship had six functions, namely 1) intimacy (companionship); 2) stimulation; 3) physical support; 4) ego support; 5) social comparison; and 6) intimacy and affection (Santrock, 2009).

Willard's research, over three decades, showed that friends could be a source of cognitive and emotion from childhood to old age. Friends can strengthen self-esteem and feelings of happiness (Santrock, 2004). In line with the study results, Cowie and Wellace (2000) also found that peer support helped or provided benefits to children who had social problems and family problems, can help improve the school climate, and provide social skills training. Berndt (1999) recognized that not all friends could provide developmental benefits. Individual development will be helped if the child has socially skilled and supportive friends. Meanwhile, friends who like to impose their will and cause a lot of conflicts will hinder development (Santrock, 2004).

Taking into account the importance of the role of peers, the development of a positive peer environment was an effective way to support adolescent development. Regarding the benefits of adolescents having a positive peer group, Laursen (2005) stated that a positive peer group allowed adolescents to feel accepted, allow adolescents to do catharsis, and test new values and new views. Furthermore, Laursen emphasized that positive peer groups provided opportunities for adolescents to help others and encouraged adolescents to develop networks to give each other positive encouragement.

Interactions among peers can be used to form meanings and perceptions and new solutions. A positive peer culture provided an opportunity for adolescents to test the effectiveness of their communication, behavior, perceptions, and values. A positive peer culture really helped teens to understand that they were not alone in facing various challenges. A positive peer culture can be used to help change adolescent attitudes and values.

\section{Self-concept towards adolescent religiosity}

There was a significant effect between the effects of self-concept on adolescent religiosity. This meant that the higher the self-concept, the higher the youth's religiosity. The study results were in line with Maisalfa's (2016) research that there was a positive and significant relationship between self-concept and students' religious behavior. The more positive or better the students' self-concept, the higher and better their religious behavior.

Rogers stated that self-concept plays a central role in human behavior. The greater the congruence between the self-concept and reality, the less the person's self-incompetence and dissatisfaction will be. This was because the way an individual perceived himself will be seen from his entire behavior. Self-concept played a role in maintaining inner harmony, interpreting experience, and determining individual expectations. This was because an unpleasant psychological situation will occur if unbalanced or conflicting feelings or perceptions arise. To eliminate this dissonance, he will change his behavior until he feels a sense of balance again and the situation becomes pleasant again (Burns, 2003).

In line with what was described above, Hurlock (2004) suggested that self-concept was the core of a person's personality development pattern, which will affect various forms of character and behavior. If the self-concept was positive, a person would develop self-confidence, self-esteem, and the ability to see himself in reality. It will foster social adjustment and create good behavior and personality. Conversely, if the self-concept was negative, individuals tended to develop feelings of inadequacy and low self-esteem. He will feel doubtful and lack self-confidence, thus fostering personal and social adjustments and bad behavior.

In addition, self-concept played a role in determining behavior because it determined individual expectations. Hope was the core of the self-concept, goals, and ideals of individuals who always wanted to achieve a pleasant inner balance. Likewise, if the self-concept was associated with religious behavior, there was a relationship between the two. As explained above that, self-concept plays a central role in human behavior. In other words, it can be stated that if a person had a positive 
self-concept, then automatically he will show or behave well, which was applied in everyday life, including in terms of his behavior in carrying out and practicing everything that was known or learned according to the guidance of Islamic teachings (Maisalfa et al., 2016).

\section{CONCLUSION}

The study concluded that single parent (father) parenting, peer conformity, and self-concept together on adolescent religiosity were very high or strong. Thus, adolescents' religiosity will be good if they were cared for properly by their fathers, had peers, and a good self-concept.

\section{DAFTAR PUSTAKA}

Abidin, U. K., \& Anam, S. (2019). Fenomena Geng Santri (Pengaruh Konformitas Kelompok Teman Sebaya terhadap perilaku Positif dan Negatif Geng Santri di Pondok Pesantren). Miyah: Jurnal Studi Islam, 13(01), 98-125.

Adiyanti, M. G., \& Sofia, A. (2014). Hubungan Pola Asuh Otoritaf Orang Tua Dan Konformitas Teman Sebaya Terhadap Kecerdasan Moral. Jurnal Pendidikan Progresif, 4(2), 133-141.

Aliyah, H. (2017). Pengaruh Pola Asuh Single Parent (Ayah) Terhadap Perilaku Keberagamaan Anak Di Desa Lumansari Kecamatan Gemuh Kabupaten Kendal.

Berndt, T. J., Hawkins, J. A., \& Jiao, Z. (1999). Influences of friends and friendships on adjustment to junior high school. Merrill-Palmer Quarterly, 45(1), 13-41.

Burns, R. B. (2003). Konsep Diri. Arcan.

Butler-Barnes, S. T., Martin, P. P., \& Boyd, D. T. (2017). African American Adolescents' Psychological Well-Being: The Impact of Parents' Religious Socialization on Adolescents' Religiosity. Race and Social Problems, 9(2), 115-126. https://doi.org/10.1007/s12552-017-9199-8

Cornwall, M. (1987). The Social Bases of Religion: A Study of Factors Influencing Religious Belief and Commitment. Review of Religious Research, 29(1), 44. https://doi.org/10.2307/3511951

Cowie, H., \& Wallace, P. (2000). Peer support in action: From bystanding to standing by. Sage.

Danny, I. Y.-I. (1991). Kepribadian Keluarga Narkotika. Arcan.

Elfida, D. (2005). Hubungan Antara Kemampuan Mengontrol Diri Dan Kecenderungan Berperilaku Delinkuen Pada Remaja. Jurnal Psikologi, 1.

Gladding, S. T. (1995). Group work: A counseling specialty. Prentice Hall.

Gunarsa. (2007). Psikologi Remaja. Gunung Mulia.

Hariz, S. A. (2013). Hubungan antara persepsi keharmonisan keluarga dan konformitas teman sebaya dengan kenakalan remaja. Persona: Jurnal Psikologi Indonesia, 2(1).

Hartaty, D. F., \& Azis, A. (2014). Hubungan Antara Pola Asuh Otoritarian Dan Konformitas Teman Sebaya Dengan Kenakalan Remaja. Analitika: Jurnal Magister Psikologi UMA, 6(1), 1-8.

Hawari, D. (1997). Alquran Ilmu Kedokteran Jiwa dan Kesehatan Mental. Dana Bhakti Yasa.

Hurlock, E. B. (2004). Psikologi Perkembangan (Soedjarmo \& Istiwidayanti (eds.)). Erlangga.

Isminayah, A. (2016). Relasi Tingkat Keharmonisan Keluarga Dengan Konsep Diri REMAJA. AlBalagh: Jurnal Dakwah Dan Komunikasi, 1(2), 233-248.

Khon, A. M. (2011). Praktikum Qira'at Keanehan Membaca Alquran Qira'at Ashim dari Hafash. Amzah.

Koenig, L. B., McGue, M., Krueger, R. F., \& Bouchard, T. J. (2005). Genetic and Environmental Influences on Religiousness: Findings for Retrospective and Current Religiousness Ratings. Journal of Personality, 73(2), 471-488. https://doi.org/10.1111/j.1467-6494.2005.00316.x

Laursen, E. K. (2005). Rather Than Fixing Kids - Build Positive Peer Cultures. Reclaiming Children and Youth, 14(3), 137-142.

Maisalfa, T., Basyir, M. N., \& Zuliani, H. (2016). Hubungan Antara Konsep Diri Dengan Perilaku Religiusitas Siswa Man Rukoh Banda Aceh. JIMBK: Jurnal Ilmiah Mahasiswa Bimbingan \& Konseling, 1(1).

Mansur. (2005). Pendidikan Anak Usia Dini dalam Islam. Pustaka Pelajar.

Padjrin, P. (2016). Pola Asuh Anak dalam Perspektif Pendidikan Islam. INTELEKTUALITA, 5(1), 1. https://doi.org/10.19109/intelektualita.v5i1.720

Paninten, G. A., \& Indrawati, E. S. (2020). Hubungan antara dukungan sosial teman sebaya dengan religiusitas pada Komunitas Cah Hijrah Semarang. Empati, 9(4), 262-279.

Papalia, D. E., Old, S. W., \& Feldman, R. D. (2010). Human Development (Psikologi Perkembangan): Bag Is/d IV.

Perdana, P. I., \& Mujiasih, E. (2018). Hubungan Antara Konformitas Teman Sebaya dengan Perilaku 
Konsumtif Membeli Pakaian pada Mahasiswi Angkatan 2016 Fakultas Psikologi Universitas Diponegoro. Jurnal Empati, 6(4), 195-208.

Perlmutter, M., \& Hall, E. (1985). Adult Development and Aging. John Wiley.

Prayugo, M. I., \& Suroso, S. (2018). Hubungan Konsep Diri Dan Konformitas Teman Sebaya Dengan Perilaku Agresif Remaja. PSIKOSAINS (Jurnal Penelitian Dan Pemikiran Psikologi), 13(1), 33. https://doi.org/10.30587/psikosains.v13i1.345

Raharjo. (2002). Pengantar Ilmu Jiwa agama. Pustaka Rizki Putra.

Retnoningtyas, M. D. (2010). Studi Korelasi antara Pola Asuh Orang Tua dan Konsep Diri dengan Ketaatan Beragama Mahasiswa Sosiologi-Antropologi Fakultas Keguruan dan Ilmu Pendidikan Universitas Sebelas Maret Surakarta.

Safitri, A. D. (2018). Pengaruh Religiusitas dan Konformitas Teman Sebaya Terhadap Gaya Hidup Hedonisme. Psikoborneo: Jurnal Ilmiah Psikologi, 6(3).

Sahrudin, S. (2017). Peran Konsep Diri, Religiusitas, dan Pola Asuh Islami terhadap Kecenderungan Perilaku Nakal Remaja Di Cirebon. Syntax Literate; Jurnal Ilmiah Indonesia, 2(1), 50-62.

Santrock, J. W. (2004). Educational psychology. McGraw-Hill.

Santrock, J. W. (2006). Life-span development. McGraw-Hill.

Santrock, J. W. (2009). Psicologia educacional. AMGH Editora.

Santrock, J. W. (2012). Perkembangan Masa Hidup. Erlangga.

Saputro, B. M., \& Soeharto, T. (2012). Hubungan antara konformitas terhadap teman sebaya dengan kecenderungan kenakalan pada remaja. Insight, 1O(1), $1-15$.

Sari, D. R. (2019). Dampak Pola Asuh Single parent Terhadap Tingkah Laku Beragama Remaja di Kabupaten Padang Lawas Utara. Jurnal Kajian Gender Dan Anak, 3(1), 33-53.

Shavelson, R. J., \& Bolus, R. (1982). Self concept: The interplay of theory and methods. Journal of Educational Psychology, 74(1), 3-17. https://doi.org/10.1037/0022-0663.74.1.3

Shundy, B. T. A., \& Purwandari, E. (2015). Pengasuhan Single Parent Pada Kasus Kenakalan Remaja.

Siroj, E. Y., Sunarti, E., \& Krisnatuti, D. (2019). Keberfungsian Agama di Keluarga, Ancaman, Interaksi Teman Sebaya, Dan Religiusitas Remaja. Jurnal Ilmu Keluarga \& Konsumen, 12(1), $13-25$.

Sisrazeni. (2018). Hubungan Pola Asuh Orang Tua dengan Kecerdasan Emosional dan Sikap Keberagamaan Mahasiswa Batusangkar. Psikoislamedia Jurnal Psikologi, 3(2), 314-331.

Smith, C. (2003). Theorizing Religious Effects Among American Adolescents. Journal for the Scientific Study of Religion, 42(1), 17-30. https://doi.org/10.1111/1468-5906.to1-1-00158

Stark, R., \& Glock, C. Y. (1993). Dalam Analisa dan Interpretasi Sosiologis. In R. Robertson (Ed.), Jakarta: Raja Grafindo Persada. Raja Grafindo Persada.

Suci, M. R. (2018). Pola Asuh Single Parent Dalam Mendorong Tingkat Ketaatan Beragama Remaja Di Desa Kuripan 1 Kecamatan Tiga Dihaji Kabupaten Oku Selatan. UIN Raden Intan Lampung.

Susanti, I., \& Handoyo, P. (2015). Perilaku penyimpangan Remaja pada Masyarakat Karangmojo Plandaan Jombang. Paradigma, 3(2).

Uhbiyati, N. (2013). Dasar-Dasar Ilmu Pendidikan Islam. Pustaka Rizki Putra.

Warsiyah. (2018). Pengaruh perilaku beragama orang tua terhadap lingkungan pendidikan, konformitas teman sebaya dan keberagamaan remaja muslim di Kota Surakarta.

Wood, S. E., Wood, E. G., \& Boyd, D. (2007). The World of Psychology. Pearson Education, Inc. 